\title{
TREATMENT OF HYPOTHYROIDISM IS IMPORTANT IN TREATING BIPOLAR AFFECTIVE DISORDER
}

\author{
Sainath Reddy.B*, Deepika.B, Harish.S
}

Malla Reddy College of Pharmacy, Maisammaguda, Dhulapally, Secunderabad- 500014, Andhra Pradesh, INDIA

*Corresponding Author's Email: sainathreddy2912@gmail.com

\begin{abstract}
:
Bipolar affective disorder along with hypothyroidism is well documented. There are few studies regarding hypothyroidism in patients with bipolar affective disorder. Here our main motto is to report such a case who was presented with bipolar affective disorder along with hypothyroidism as a co-morbidity \& to provide a brief information regarding association of hypothyroidism in bipolar affective disorder. Treatment approaches in such co-morbid conditions.
\end{abstract}

Keywords: Bipolar affective disorder, Hypothyroidism, Co-morbidity.

\section{INTRODUCTION:}

Bipolar Affective Disorder: Bipolar disorder (also known as manic depression) causes serious shifts in mood, energy, thinking, and behavior from the highs of mania on one extreme, to the lows of depression on the other ${ }^{1}$. It is a medical complex- illness and also known as manic depression disorders ${ }^{2}$. The term "manicdepressive illness" or psychosis was coined by German psychiatrist Emil Kraepelin in the late nineteenth century, originally referring to all kinds of mood disorder. But, German psychiatrist Karl Leonhard split the classification in 1957, employing the terms unipolar disorder (major depressive disorder) and bipolar disorder ${ }^{3}$.

Hypothyroidism: Hypothyroidism, it is commonly characterised by abnormal production of thyroid hormones. Thyroid hormone mainly acts as a neurotransmitter. The imbalance in thyroid hormones mainly mimics or shows similar symptoms that are associated with psychiatric disease ${ }^{4}$. The symptoms associated with hypothyroidism are fatigue, depression, cold intolerance and excessive sleepiness etc.

Many studies suggest that the hypothyroidism is a most commonly found abnormality in bipolar affective disorder. Some studies also suggest that lithiumtreatment has a potential to exacerbate a preexisting hypothyroid state or to induce hypothyroidism.

\section{CASE REPORT:}

A 44 yrs old man was admitted to Malla Reddy medical college hospital and research center, Suraram with chief complaints of fatigue, depression and cold intolerance since 1 week. This patient was a known case bipolar affective disorder which was previously diagnosed and treated in NIMS 2013. He is an employee in manufacturing industry for past 7 years. $\mathrm{He}$ is on following treatment with Tab. Lithium-300mg BID, Tab. Clozapine-30mg/day, Tab. Haloperidol-10mg/day and in social history he is alcoholic and smoker.

\section{Lab Investigations:}

\begin{tabular}{|l|l|l|l|l|l|l|l|l|l|l|}
\hline Blood Sugar (mg\%) & Day1 & Day2 & & & & & & & & \\
\hline Blood Sugar Fasting(70-110) & 80 & N & & & & & & & & \\
\hline Blood Sugar Post Lunch(70-150) & 110 & N & & & & & & & & \\
\hline Blood Sugar Random(80-120) & 90 & N & & & & & & & & \\
\hline
\end{tabular}




\begin{tabular}{|c|c|}
\hline Complete Blood Picture & Liver Function Test \\
\hline \multirow{3}{*}{$\begin{array}{l}\mathrm{Hb}(\mathrm{g} / \mathrm{dl})(\mathrm{M}-11-16 \mathrm{~F}-11-14): 12 \\
\mathrm{RBC}(\mathrm{mill} \text { cells/cumm })(4-6.5): 4.6 \\
\mathrm{WBC}(\mathrm{cells} / \mathrm{cumm})(4000-11000): 7,500 \\
\text { Differential Leukocyte Count } \\
\text { Neutrophils(40-75\%) : 65\% } \\
\text { Lymphocytes(20-45\%):30\% } \\
\text { Eosinophils(01-06) :5\% } \\
\text { Monocytes(02-10\%):2\% } \\
\text { Basophils(upto 1): } \\
\text { Platelet Count }(1.5-4.5 \text { lakhs/cumm) : Adequate } \\
\text { Peripheral Smear } \\
\text { RBCs : } \\
\text { WBCs : }\end{array}$} & $\begin{array}{l}\text { Serum Bilirubin Total(upto } 1 \mathrm{mg} / \mathrm{dl}): 0.7 \\
\text { Direct (upto } 0.25 \mathrm{mg} / \mathrm{dl}): \mathrm{N} \\
\text { Indirect : } \\
\text { SGPT (upto 65 IU/L) }: 44 \\
\text { SGOT (upto } 37 \mathrm{IU} / \mathrm{L}): 33 \\
\text { Alkaline Phosphatase }(15-116 \mathrm{IU} / \mathrm{L}): 110 \\
\text { Total Proteins }(6-8 \mathrm{gm} / \mathrm{dl}): 7 \\
\text { Albumin }(3.2-5.8 \mathrm{gm} / \mathrm{dl}): \mathrm{N} \\
\text { Globulin }(2.2-4.8 \mathrm{gm} / \mathrm{dl}): \mathrm{N}\end{array}$ \\
\hline & Lipid Profile (mg/dl) \\
\hline & \multirow{3}{*}{$\begin{array}{l}\text { Total Cholesterol }(140-250): 220 \\
\text { HDL Cholesterol }(30-65): 45 \\
\text { LDL Cholesterol }(80-180): 90 \\
\text { VLDL Cholesterol }(5-45): 35 \\
\text { Triglycerides (25-160) }: 140 \\
\text { TC/HDL Ratio (upto 4.5) }: \mathrm{N}\end{array}$} \\
\hline ESR (M-0-10mm/hr F-0-20mm/hr) : & \\
\hline Urine Analysis & \\
\hline \multirow{4}{*}{$\begin{array}{l}\text { Color : } \\
\text { Appearance : } \\
\text { Pus Cells : } \\
\text { Albumin : } \\
\text { Epithelial Cells : } \\
\text { Glucose : } \\
\text { RBC : }\end{array}$} & Biochemical Investigations (mg/dl) \\
\hline & $\begin{array}{l}\text { Serum Creatinine (0.6-1.4) : } 1.2 \\
\text { Blood Urea }(14-45): 40\end{array}$ \\
\hline & Serum Electrolytes $(\mathrm{mmols} / \mathrm{L})$ \\
\hline & Serum Sodium(135-155) : 140 \\
\hline Thyroid Functions Test & $\begin{array}{l}\text { Serum Potassium }(3.6-5.5): 4.2 \\
\text { Serum Chlorides }(98-108): \mathrm{N}\end{array}$ \\
\hline $\begin{array}{l}\mathrm{T}_{3}(60-181 \mathrm{ng} / \mathrm{dl}): 35 \mathrm{ng} / \mathrm{dl}-- \text { DECREASED } \\
\mathrm{T}_{4}(7.3-15 \mu \mathrm{g} / \mathrm{dl}): 4.3 \mu \mathrm{g} / \mathrm{dl}-- \text { DECREASED } \\
\mathrm{TSH}(0.55-4.78 \mu \mathrm{IU} / \mathrm{L}): 6.7---I N C R E A S E D\end{array}$ & $\begin{array}{l}\text { Serum Chlorides }(98-108): \mathrm{N} \\
\text { Serum Phosphates }(2.5-5)): \mathrm{N} \\
\text { Serum Calcium }(8-10.8): \mathrm{N}\end{array}$ \\
\hline
\end{tabular}

\section{DISCUSSION;}

Bipolar affective disorder is a complex medical illness. It is mainly characterised by serious shifts in mood, energy, thinking, and behavior-from the highs of mania on one extreme, to the lows of depression on the other. In this present case, the patient had a past history of bipolar affective disorder, admitted and treated in NIMS hospital. He is on following treatment with Tab. Lithium-300mg BID, Tab. Clozapine-30mg/day, Tab. Haloperidol-10mg/day.

Currently, the patient was admitted in the hospital with chief complaints of fatigue, depression and cold intolerance since 1 week. Inspite of use of antidepressant drugs the patient's bipolar affective disorder symptoms were not controlled. When the patient blood parameters were investigated, it was founded that there was a decrease in $\mathrm{T}_{3}, \mathrm{~T}_{4}$ and increase in TSH levels. With the subjective (symptoms) and objective (lab investigation) the patient has diagnose with hypothyroidism. Here in this présent case, the main etiological factor for hypothyroidism is use of lithium (an antipsychotic drug used for treating bipolar affective disorder).

The mechanism with which lithium induces hypothyroidism or excerbate the hypothyroidism is complex ${ }^{5}$. Lithium gets concentrâtes in the thyroid gland and inhibits thyroidal iodine uptake.It also inhibits iodotyrosine coupling, alter thyrolobulin structure, inhibits thyroid hormones excretion and interferes with the deiodination of T4 to T3 by inhibiting type -II deiodinase in the brain. Johnston and Eagles found a $10.4 \%$ prevalence of clinical hypothyroidism in patients who are on lithium therapy ${ }^{6}$.

Kupka et al. found thyroperoxidase antibodies in 64 of $226(28 \%)$ outpatients with bipolar disorder, ${ }^{7}$ a rate higher than general population subjects. Although, lithium is most effective in treating bipolar affective disorder, it has potential to cause hypothyroidism by the above stated mechanism. Because lithium has ability to cause hypothyroidism, the patient thyroid profile should be carefully examined before initiating lithium therapy and if patient found to be hypothyroid than thyroid supplementation should be initiated.

Some studies suggest that the patients with bipolar disorder, supraphysiological doses of T4 is mainly usefull as a supplement for prophylactic efficacy of mood stabilizing agents. It is also use to augment the antidepressant treatment.

Bauer and Whybrow conducted the first open label trial of adjunctive supraphysiologicaldoses of T4 in 11 patients with treatment-refractory bipolar affective disorder ${ }^{8}$. Adjunctive treatment withT4 reduced the severity of manic and the depressive phases in both amplitude and frequency,and even led to complete remission in some patients. Thyroxine was used in doses of $250-500 \mathrm{mcg} / \mathrm{day}$ in these studies, the goal was to achieve TSH suppression by increasing free T4 levels by 
$>50 \%$ of pretreatment levels. Despite concerns about adverse effects, ${ }^{9}$ the treatment was rated favourably by recipients and was well tolerated ${ }^{10}$

Two of the more recent studies have attempted thyroid hormone augmentation of patients with refractory bipolar depression using slightly different strategies. Łojko et al. found addition of moderate doses of $\mathrm{T} 4$ (100 $\mathrm{mcg} / \mathrm{day})$ to be a successful augmentation strategy in female patients with bipolar depression, who had an unsatisfactory response to serotonergic antidepressants ${ }^{11}$. Another retrospective chart review of 125 patients with treatment resistant bipolar depression showed augmentation with high dose T3 to be highly effective ${ }^{12}$.

In this present case, augmentation with thyroxine at a intial dose of $50-100 \mathrm{mcg} /$ day and increased by $25-50$ mcg per week, to a maximum of 500 mcg per day showed a dramatic improvement in bipolar affective disorder symptoms and patient thyroid profile.

\section{REFFERENCES;}

1. Available URL; http://www.helpguide.org/mental/bipolar_disorder_symptom s treatment.

2. Management of Bipolar Disorder in Adults, Children and Adolescents in Primary and Secondary care by the National Collaborating Centre for Mental Health (NCCMH). 2006: 70

3. Available

URL; http://www.medicinenet.com/bipolar_disorder.

4. Steven I. Sherman and Robert L. Talbert, Thyroid disorders. In:Pharmacotherapy; A Pathophysiologic Approach, 7thed. Dipiro JT, Talbert RL, Yee GC, et al., eds. Newyork: McGraw-Hill;2008:1243-64.

5. Lazarus JH. The effects of lithium therapy on thyroid and thyrotropin-releasing hormone. Thyroid, 1998;8:909-913.

6. Johnston AM. Eagles JM. Lithium-associated clinical hypothyroidism. Prevalence and risk factors. British Journal of Psychiatry, 1999, 175, 336 -339.

7. Kirov G, Tredget J, John R, Owen MJ, Lazarus JH. A crosssectional and a prospective study of thyroid disorders in lithium-treated patients. J Affect Disord. 2005;87:313-317. doi: 10.1016/j.jad.2005.03.010.

\section{CONCLUSION;}

According to our study we conclude that the lithium treatment has a potential to exacerbate a preexisting hypothyroid state or to induce hypothyroidism. Because lithium has ability to cause hypothyroidism, the patient thyroid profile should be carefully examined before initiating lithium therapy and if patient found to be hypothyroid than thyroid supplementation should be initiated. Several studies suggest that the use of supraphysiological doses of thyroxine in patients with bipolar affective disorder showed better improvement in symptoms. So, attention should be showed on the thyroid profile of the patient with bipolar affective disorder and thyroxine augmentation should be done based on patient's thyroid profile. Special precautions are required in those with endocrine or cardiovascular disorders. Administration during pregnancy is not recommended.

8. Bauer MS, Whybrow PC, "Rapid cycling bipolar affective disorder. II. Treat ment of refractory rapid cycling with high dose levothyroxine: a preliminary study," Archives of General Psychiatry, vol. 47, no.5, pp. 435-440, 1990.

9. Bauer MS, Whybrow PC, Whybrow, "Rapid cycling bipolar affective disorder. II. Treat ment of refractory rapid cycling with high dose levothyroxine: a preliminary study," Archives of General Psychiatry, vol. 47, no.5, pp. 435-440, 1990.

10. Bauer MS, Priebe AB, erghofer TB, Schor U. Kiesslinger,and P.C.Whybrow, "Subjective response to and tolerability of long-term supraphysiological doses of levothyroxine in refractory mood disorders," Journal of Affective Disorders , vol.64, no. 1, pp. 35-42, 2001.

11. Łojko D, Rybakowski JK, " l-thyroxine augmentationof serotonergic antidepressants in female patients with refractory depression," Journal of Affective Disorders, vol. 103, no. 1-3, pp. 253-256, 2007.

12. Kelly T, Lieberman DZ, " The use of triiodothyronine as an augmentation agent in treatment resistant bipolar II and bipolar disorder NOS," Journal of Affective Disorders, vol. 116, no. 3, pp. 222-226, 2009. 